\title{
The catalytic role of uranyl in formation of polycatechol complexes
}

Prashant Kumar Jha*, Gary P Halada

\begin{abstract}
To better understand the association of contaminant uranium with natural organic matter (NOM) and the fate of uranium in ground water, spectroscopic studies of uranium complexation with catechol were conducted. Catechol provides a model for ubiquitous functional groups present in NOM. Liquid samples were analyzed using Raman, FTIR, and UV-Vis spectroscopy. Catechol was found to polymerize in presence of uranyl ions. Polymerization in presence of uranyl was compared to reactions in the presence of molybdate, another oxyion, and self polymerization of catechol at high $\mathrm{pH}$. The effect of time and dissolved oxygen were also studied. It was found that oxygen was required for self-polymerization at elevated $\mathrm{pH}$. The potential formation of phenoxy radicals as well as quinones was monitored. The benzene ring was found to be intact after polymerization. No evidence for formation of ether bonds was found, suggesting polymerization was due to formation of C-C bonds between catechol ligands. Uranyl was found to form outer sphere complexes with catechol at initial stages but over time (six months) polycatechol complexes were formed and precipitated from solution (forming humic-like material) while uranyl ions remained in solution. Our studies show that uranyl acts as a catalyst in catechol-polymerization.
\end{abstract}

\section{Introduction}

Uranium is present in our environment due to its natural occurrence, mining, processing and subsequent use. Radionuclides from mill sites, nuclear facilities and waste disposal sites can be spread by air and groundwater which necessitates the study of uranium transport and reactions in the environment: a number of such studies have been conducted [1-8]. Many factors affect the speciation and transportation of uranium in soil and groundwater including minerals in soil, nature and amount of organic matter in soil, $\mathrm{pH}$ of soil and water, rate and direction of groundwater flow, and hydraulic gradient [9]. Contaminant uranium in the subsurface has been found in very diverse forms including as uranyl phosphate, uranyl hydroxide, and an ill-defined uranyl organic phase at Fernald [10]. In studies conducted at Oak Ridge National Laboratory, uranyl has been found to exist complexed with phosphates and carbonates, associated with iron and manganese phosphates [1], and complexed with soil organic matter [11].

Humic substances form the majority of natural organic matter (NOM) in soil. Humic substances are high

\footnotetext{
* Correspondence: pjha@ic.sunysb.edu

Department of Materials Science and Engineering and the Center for Environmental Molecular Science Stony Brook University, Stony Brook, New York 11794-2275, USA
}

molecular weight, naturally occurring complex aggregates of aliphatic and aromatic chains having a number of common functional groups. Humic substances interact with metal ions through functional groups, forming soluble complexes, precipitating metal ions by reduction or by ion exchange, modifying the sorption behavior of mineral surfaces towards metal ions and modifying colloidal particles containing metal ions [12]. More than 40 binding sites for complexation have been reported for humic materials including carboxylate, carbonyl, polyphenolic and amine functional groups [13]. Catechol (o-diphenol benzene) is the simplest aromatic molecule containing highly reactive diphenol groups similar to many larger polyphenols constituting humic material, which makes catechol an ideal candidate for study of metal ion association relevant to contaminant mobility in soils. Due to its common presence as a functional group in NOM, catechol is also an ideal candidate for the study of oxidative polymerization [14]. Oxidative polymerization is an important process to understand because of its role in humic polymers originating from decomposition of plant residue [15].

In addition to the relevance of using catechol as a model ligand to understand reactions of mobile metal ions with subsurface organic constituents, catechol itself 
in the subsurface originates from both natural and manmade sources. It is produced in nature by bacterial degradation of plants and animals [15]. Catechol and other phenolic compounds are produced by many chemical industries and need to be removed from wastewater discharged by those industries [16]. While catalytic polymerization of catechol was first demonstrated by Ziechmann using silica [17], it has also been observed using alumina, $\mathrm{FeO}, \mathrm{MnO}, \mathrm{Ag}_{2} \mathrm{O}$, soil, silver colloids [14] and various enzymes, including laccase [16], horseradish peroxidase and soybean peroxidase [18]. These enzymes, along with an oxidizing agent (hydrogen peroxide/dissolved oxygen), oxidize phenols to the phenoxy radical. In turn, the generated phenoxy radicals associate to form dimers, trimers and polymers [19]. Abiotic oxidative polymerization of phenolic compounds was investigated by Colarieti et al. al using soil samples, and it was established that both soil and dissolved oxygen are required for polymerization [20]. These authors later formulated a three step mechanism for abiotic oxidation of catechol: (1) catechol is oxidized by metal oxide( $\mathrm{Fe}$ and $\mathrm{Mn}$ oxides) and the metal oxide is reduced (2) complexation occurs between the reduced metal and remaining catechol, and (3) the metal-catechol complex is oxidized by dissolved oxygen to form polymers [21].

In this study we have investigated uranyl $\left(\mathrm{UO}_{2}{ }^{2+}\right)$ interactions with catechol using spectroscopic techniques including Raman, FTIR and UV-vis spectroscopies. Catechol was found to polymerize in the presence of uranyl. Catechol polymerization was further investigated for effects of $\mathrm{pH}$ and dissolved oxygen and presence of other oxyions. Molybdate was used for comparison as it is well known oxidizer, and molybdenum is a known catalyst for benzene hydroxylation [22]. Moreover, molybdenum occurs naturally with uranium and is present in the form of $\mathrm{MoO}_{4}{ }^{2-}$ in leach solutions generated during hydrometallurgical extraction of uranium [23]. Molybdenum is also present in spent fuel rods formed by fission of uranium and beta decay of niobium, where it is found that $\mathrm{Mo}^{6+}$ converts to $\mathrm{MoO}_{2}{ }^{2+}$ under oxidizing condition with an ionic potential similar to $\mathrm{UO}_{2}{ }^{2+}[24]$. For these reasons as well as the fact that molybdenum itself is a contaminant in groundwater[25] makes molybdate an ideal candidate for comparison with uranyl.

\section{Experimental}

\subsection{Synthesis of complexes}

$0.1 \mathrm{M}$ aqueous solutions of catechol (o-dihydroxybenzene, Aldrich chemical Corp.), uranyl nitrate(Analar, BDH Chemicals Ltd.) and sodium molybdate(Aldrich Chemical Corp.) were prepared by dissolution in DI $(>18 \mathrm{M} \Omega / \mathrm{cm})$ water. To obtain complexes, catechol was added to uranyl nitrate and sodium molybdate in 1:1 volume ratios. All the solutions as well as 1:1 molar ratio complexes were adjusted to $2,4,6,8,10$ and $12 \mathrm{pH}$ using $1 \mathrm{M}$ and $0.1 \mathrm{M} \mathrm{NaOH}$ and $\mathrm{HCl}$ solutions. The pHs of solution were measured using a Corning Scholar $425 \mathrm{pH}$ meter. Solutions and complexes were analyzed using UV-Vis, Raman and IR-ATR spectroscopy. Spectra of solutions of uranyl nitrate and sodium molybdate at various $\mathrm{pH}$ were taken before spectra of uranyl-catechol and catechol-molybdate to distinguish effects of complexation from the effect of $\mathrm{pH}$ change.

\subsection{FTIR}

A Nicolet Model Magna 760 FTIR spectrometer with a ZnSe ATR crystal was used for analysis. Solutions containing complexes were placed on the crystal (in their liquid state). A $4 \mathrm{~cm}^{-1}$ resolution was used and 256 scans were averaged to improve the signal-to-noise ratio. The range selected for data acquisition was $3000-900 \mathrm{~cm}^{-1}$ (below $900 \mathrm{~cm}^{-1}$ noise was too high for meaningful signal to be observed). DI water $(>18 \mathrm{M} \Omega /$ $\mathrm{cm}$ ) was chosen as background to minimize signal from water peaks during data collection.

\subsection{Raman}

A Nicolet Almega dispersive Raman spectrometer with a $785 \mathrm{~nm}$ laser source was used for analysis. Samples were put on a gold slide as droplets and the Raman microscope was focused at the gold-solution interface. Data from averaging 256 scans in the $3444-108 \mathrm{~cm}^{-1}$ range was collected. OMNIC for Nicolet Almega software version 7.3 was used to process data.

\subsection{UV-Vis}

UV-Vis measurements were taken using an Ocean Optics S2000 spectrometer and OOIBase32 operating software. For UV-Vis measurements $1 \mathrm{mM}$ samples were used; deionized water was used as reference spectrum. Spectra were collected with $80 \mathrm{mSec}$ integration time with an average of 10 measurements.

For anaerobic UV-Vis measurements $1 \mathrm{mM}$ catechol solution was deaerated by bubbling nitrogen through the solution for four hours. $\mathrm{NaOH}$ pellets were then added to solution until $\mathrm{pH}$ was greater than 12 while the solution continued to be deaerated with nitrogen. This anaerobic catechol solution at high $\mathrm{pH}$ was then transferred to a quartz cuvette and which remained capped for the initial measurement: for subsequent readings the cap was removed to allow air to interact with the solution.

\section{Results and discussion}

3.1 Impact of pH on uranyl nitrate and sodium molybdate FTIR analysis (Figure 1) of uranyl nitrate at different $\mathrm{pH}$ shows a shift to lower wavenumbers of the peak associated 


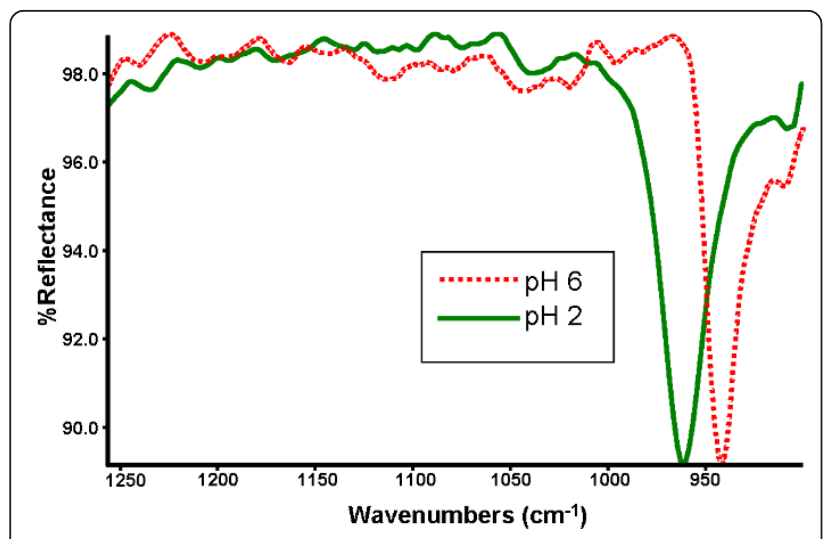

Figure 1 FTIR spectra of uranyl ion in solution at $\mathrm{pH} 6$ and precipitate at $\mathrm{pH} 6$.

with the $\mathrm{U}=\mathrm{O}$ antisymmetric stretching frequency of uranyl with an increase in $\mathrm{pH}$, shifting from $961 \mathrm{~cm}^{-1}$ at $\mathrm{pH} 2$ in solution to $942 \mathrm{~cm}^{-1}$ in the precipitate formed at $\mathrm{pH} 6$. On further increasing the $\mathrm{pH}$ the signal became lost in the background noise.

The observed shift is likely due to the presence of a greater number of hydroxyl ions coordinated with the uranyl ion, due to of the formation of different uranyl hydroxides at different pHs. In general there are more than 20 uranyl oxide hydrates [26] which may be formed at elevated $\mathrm{pH}$. Uranyl hydroxide was found to have precipitated out of solution at high $\mathrm{pH}$ as indicated by the disappearance of the uranyl peak in spectra from solution at $\mathrm{pH} 6$ and its subsequent appearance in the precipitate. Raman analysis (Figure 2) showed similar results: there is a significant decrease in stretching frequency of the $\mathrm{U}=\mathrm{O}$ uranyl peak from $875 \mathrm{~cm}^{-1}$ at $\mathrm{pH}$ 2 to 794 at $\mathrm{pH} 12$ (observed in solution up to $\mathrm{pH} 4$ and in precipitate from $\mathrm{pH}$ 6-12). This decrease in frequency is a known indicator of complexation, and indicates the presence of various uranyl hydroxides [27]. Samples

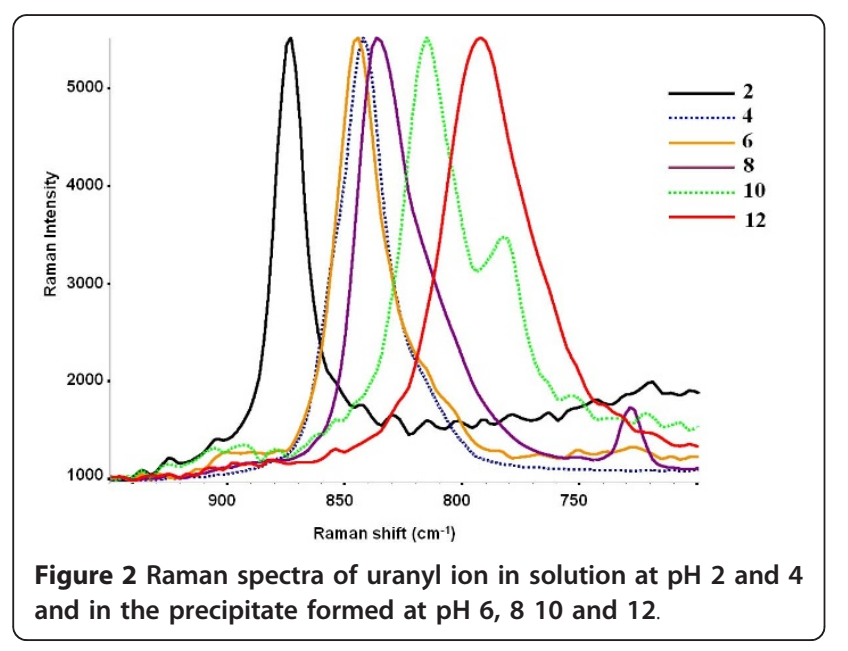

were stored in closed containers limiting the amount of atmospheric carbon dioxide absorption by solution to avoid formation of uranyl carbonate. No peaks corresponding to uranyl-carbonate $\left(1117 \mathrm{~cm}^{-1}\right)$, even at high $\mathrm{pH}$, were found.

Raman spectra from the molybdate solution (Figure 3) also show a shift in the peak associated with the Mo-O vibrational frequency in molybdate from 960 to $902 \mathrm{~cm}^{-}$ ${ }^{1}$ with increase in $\mathrm{pH}$, but the change in frequency with $\mathrm{pH}$ is not gradual as in the case of the uranyl peak. The peak at $960 \mathrm{~cm}^{-1}$ starts to lose intensity for $\mathrm{pH}$ greater than 4 while a new peak at $902 \mathrm{~cm}^{-1}$ gains intensity to $\mathrm{pH}$ 6: there is no peak at $960 \mathrm{~cm}^{-1}$ at pH 8 and above. This shift is due to the fact that molybdate structure changes with $\mathrm{pH}$ in basic and neutral solutions: it normally exists as simple tetrahedral molybdate ion, but at $\mathrm{pH}$ lower than 6 it exists as heptamolybdate $\left[\mathrm{Mo}_{7} \mathrm{O}_{24}\right]^{6-}$. This transition is complete at $\mathrm{pH} 4.5$ [28].

\subsection{Polymerization of Catechol at Elevated pH}

The $0.1 \mathrm{M}$ catechol solution was found to become increasingly opaque with increasing $\mathrm{pH}$. The solution first became brown in appearance at $\mathrm{pH} 6$ and, on further increasing the $\mathrm{pH}$ to 8 or higher, it turned black (Figure 4). UV-Vis spectra of the solutions show a peak in the range of $250-300 \mathrm{~nm}$ at all pHs: this is characteristic of $\pi-\pi^{*}$ electron transitions in phenolic compounds [29]. The change in color of the catechol solution was found to be associated with a bathochromic shift and an increase in intensity in the UV-vis absorption spectra indicating a greater degree of $\pi$-conjugation and thus polymerization [30-32] (Figure 5). A new peak $\sim 320 \mathrm{~nm}$ emerges at higher $\mathrm{pH}$ indicative of formation of a higher molecular weight polymer at higher $\mathrm{pHs}[33,29]$.

Dissolved oxygen was found to play a role in polymerization, since in absence of oxygen no change in color associated with polymerization was observed even at $\mathrm{pH}$ as high as 12. In addition, the UV-Vis peak at $320 \mathrm{~nm}$ is

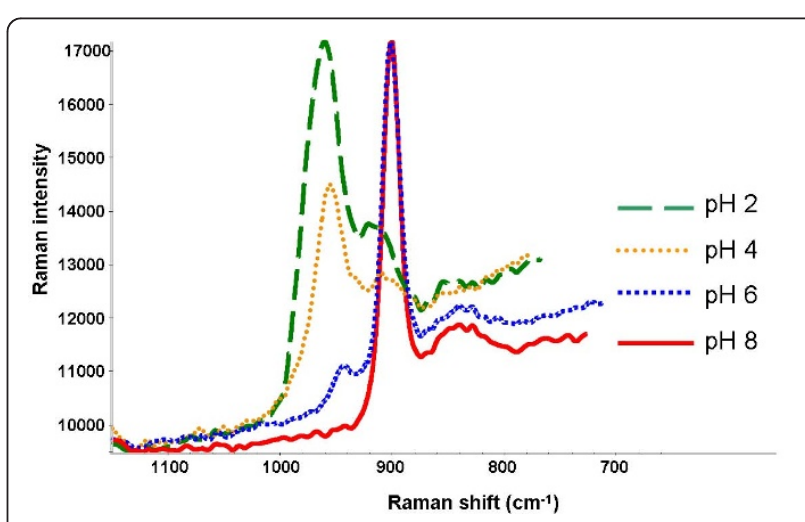

Figure 3 Raman spectra of molybdate ion In solution at $\mathrm{pH} 2$, 4, 6 and 8. 


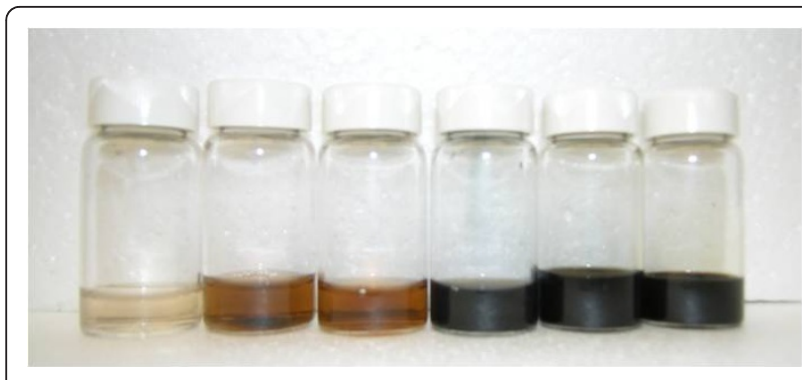

Figure 4 Catechol solutions $(0.1 \mathrm{M})$ at $\mathrm{pH} 2,4,6,8,10$ and 12 (left to right).

initially absent (figure 6 at $t=0$ ). The peak slowly emerges as air is allowed to interact with the solution and can be clearly seen after four hours $(t=240)$.

FTIR analysis (Figure 7) of the catechol solution at $\mathrm{pH}$ 2 and $\mathrm{pH} 12$ shows clear evidence of the formation of polycatechol. The four absorption peaks between 1466 and $1515 \mathrm{~cm}^{-1}$ may be attributed to aromatic ring $C=$ $\mathrm{C}$ vibration bands characteristic of the benzene ring. Peaks at 1277 and $1260 \mathrm{~cm}^{-1}$ are due to C-O vibration [34]. The broad peak at $1600 \mathrm{~cm}^{-1}$ is a combination of $\mathrm{C}=\mathrm{C}$ and substituted benzene ring vibrations. Peaks at 1202 and $1102 \mathrm{~cm}^{-1}$ observed at pH less than 6 are attributed to $\mathrm{C}-\mathrm{H}$ in-plane vibrations. Analysis from the solution at $\mathrm{pH} 12$ showed $\mathrm{C}=\mathrm{C}$ vibration bands between 1410-1584 $\mathrm{cm}^{-1}$, consistent with the formation of polycatechol. The peak at $1487 \mathrm{~cm}^{-1}$, found to appear at $\mathrm{pH}$ higher than 8 , is attributed to substituted benzene ring vibrations (which is indicative of catechol chelation and/or higher substitution). In addition, peaks associated with $\mathrm{C}-\mathrm{H}$ vibrations were not found in spectra from the $\mathrm{pH} 12$ solution.

Raman analysis (Figure 8) of catechol at different $\mathrm{pH}$ is also consistent with the formation of polycatechol. The spectra for lower $\mathrm{pH}(2,4,6)$ solution show in-plane and out-of plane $\mathrm{CH}$ deformation bands at 1040 and

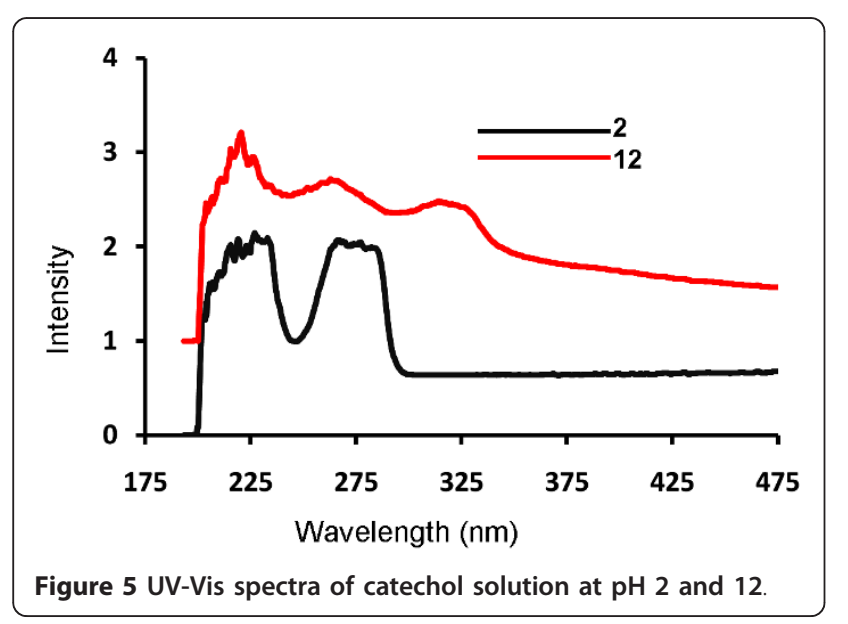

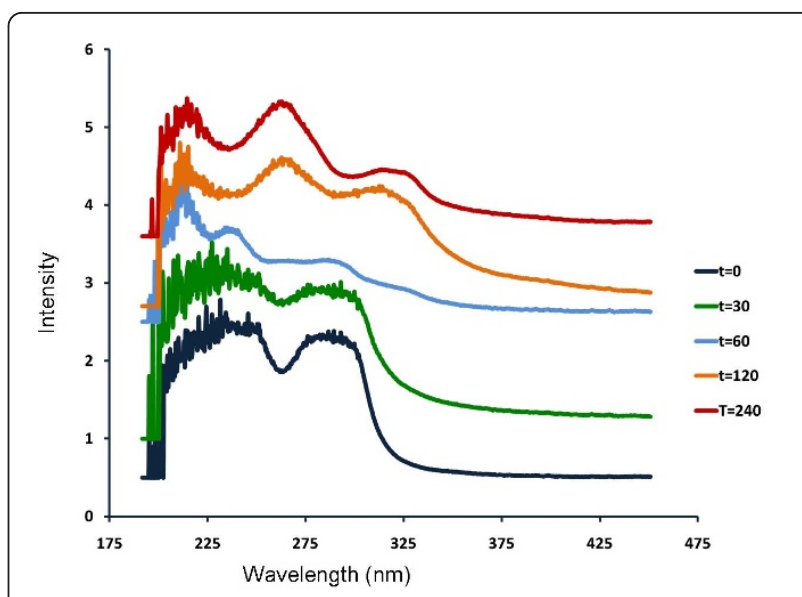

Figure 6 UV-vis spectra showing polymerization of catechol in solution at $\mathrm{pH} 12$ with exposure to air with time.

$774 \mathrm{~cm}^{-1}$. These peaks are absent at higher $\mathrm{pH}(8,10$, 12). A new peak associated with the phenoxy radical appears at $1494 \mathrm{~cm}^{-1}$. New peak at $1382 \mathrm{~cm}^{-1}$ associated with in plane $\mathrm{C}-\mathrm{H}$ rocking vibration was also observed indicating retention of some $\mathrm{C}-\mathrm{H}$ bonds in polycatechol. In addition, a new peak was observed at $1584 \mathrm{~cm}^{-1}$ indicating formation of tropones. From this evidence it appears polymerization is taking place by formation of $\mathrm{C}-\mathrm{C}$ bonds between benzene rings following deprotona-

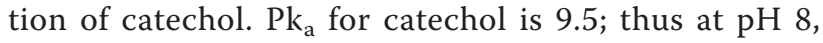
approximately $3 \%$ of the catechol will be deprotonated, likely enough to start polymerization (figure 9).

\subsection{Catechol complexes in the presence of uranyl and molybdate}

Addition of uranyl ion to catechol solution was found to induce polymerization at a significantly lower $\mathrm{pH}$ than the $\mathrm{pH}$ required for polymerization in a pure catechol solution: the uranyl/catechol solution was found to

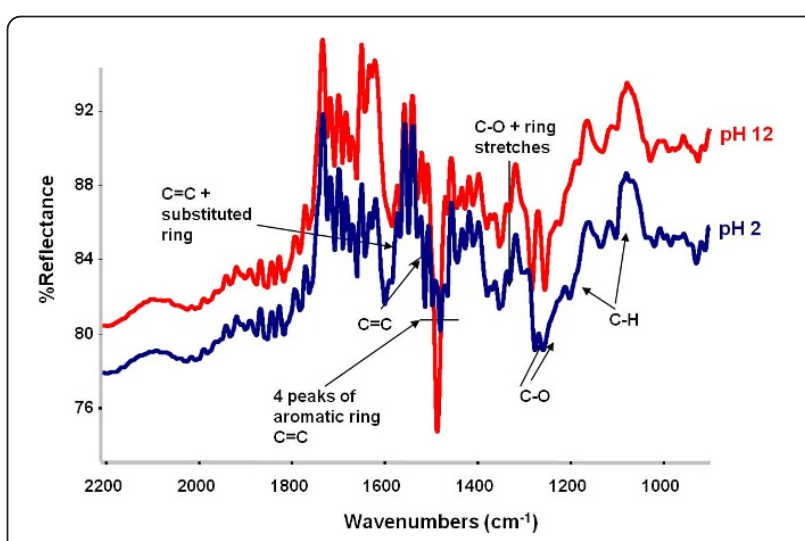

Figure 7 FTIR spectra of catechol $(\mathrm{pH} 2)$ and polycatechol (pH 12). 


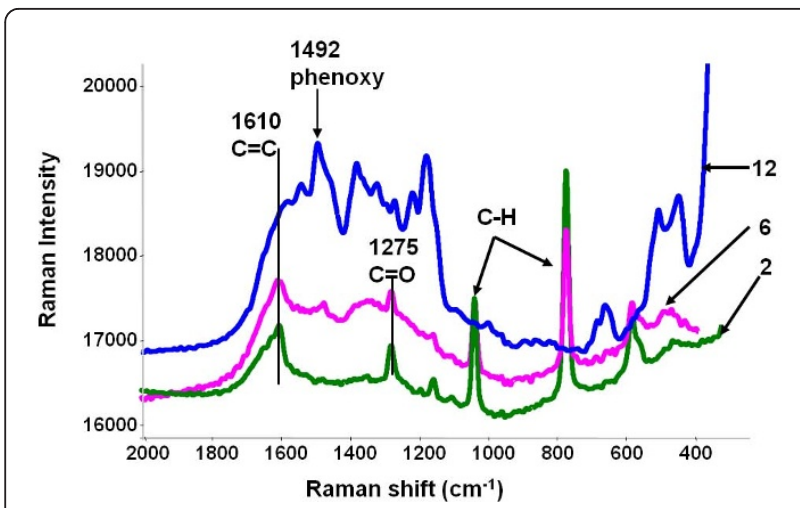

Figure 8 Raman spectra of catechol and polycatechol at $\mathrm{Ph} 2$, 6 and 12 .

become dark instantaneously at pH 6. FTIR spectra of the uranyl/catechol solution (Figure 10) shows proof of complexation by increase in intensity of the peak due to the substituted benzene ring at $1488 \mathrm{~cm}^{-1}$ as well as an increase in intensity of the peak associated with the C-O band at $1252 \mathrm{~cm}^{-1}$. No major difference in spectra was observed between solutions of 1:1 and 1:2 ratio of uranyl:catechol. Raman spectrum (Figure 11) from the uranyl-catechol solution confirmed polymerization at low $\mathrm{pH}$ : $\mathrm{C}-\mathrm{H}$ bands at 1052 and $774 \mathrm{~cm}^{-1}$ were present only at $\mathrm{pH}$ 2. The shift in the $\mathrm{C}=\mathrm{C}$ peak to $1582 \mathrm{~cm}^{-1}$ as well as the appearance of the peak associated with phenoxy groups at $1497 \mathrm{~cm}^{-1}$ were observed at $\mathrm{pH}$ as low as 2 .

By visual observation it appeared that sodium molybdate had a similar and more intense effect on catechol than uranyl nitrate, as color change was observed even at $\mathrm{pH} 2$ in fresh solution (as opposed to the requirement for a $\mathrm{pH} 6$ for the uranyl-catechol solution). Molybdate is capable of catalyzing polymerization at even more acidic $\mathrm{pH}$ due to its high affinity for aromatic o-dihydroxy compounds [35] as shown by the FTIR spectrum of the molybdate/catechol solution. At pH 6 (Figure 10), the substituted benzene ring intensity at $1483 \mathrm{~cm}^{-1}$

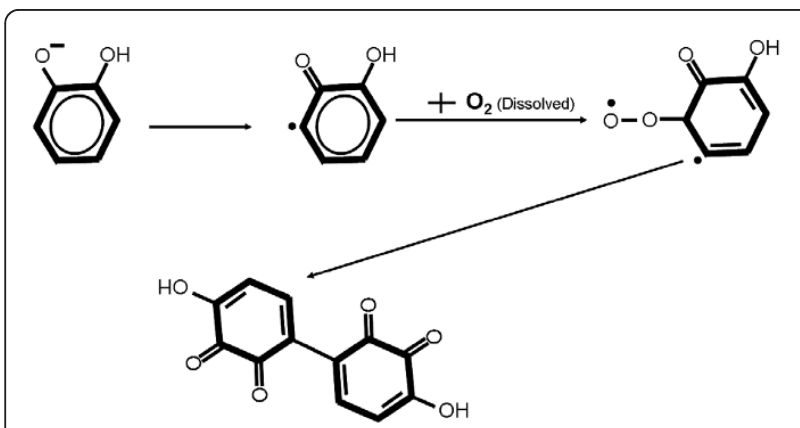

Figure 9 Proposed mechanism of initiation of catechol polymerization at high $\mathrm{pH}$.

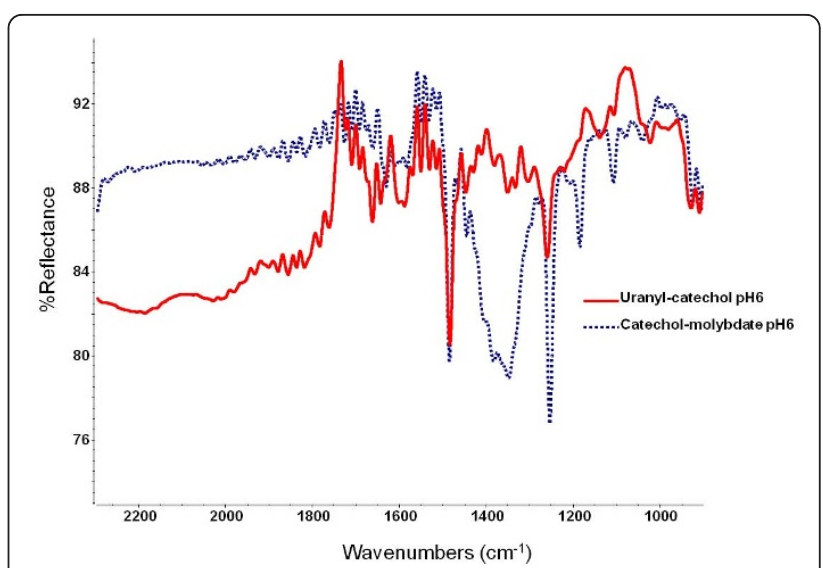

Figure 10 FTIR spectra of 1:1 uranyl-catechol and 1:1 molybdate-catechol complexes at $\mathrm{pH} 6$.

increased accompanied by a larger increase in the $\mathrm{C}-\mathrm{O}$ band at $1264 \mathrm{~cm}^{-1}$ than in the case of uranyl association with catechol at $\mathrm{pH} 6$. The results indicate that oxygen substitution is much faster in presence of molybdate as opposed to uranyl at acidic $\mathrm{pH}$. In the Raman spectrum (Figure 11) from the molybdate/catechol solution, $\mathrm{C}-\mathrm{H}$ bands were not present at any $\mathrm{pH}$, and the $\mathrm{C}=\mathrm{C}$ peak was shifted to $1563 \mathrm{~cm}^{-1}$ showing substitution and conjugation. The peak associated with $\mathrm{Mo}=\mathrm{O}$ stretching in molybdate was also shifted from 900 to $932 \mathrm{~cm}^{-1}$ showing evidence of complexation with catechol.

In all cases, whether by $\mathrm{pH}$-induced polymerization of pure catechol solution or whether catalyzed by uranyl or molybdate ions at lower $\mathrm{pH}$, it seems the mechanism of catechol polymerization is by formation of $\mathrm{C}-\mathrm{C}$ bonds between benzene rings and not by $\mathrm{C}-\mathrm{O}-\mathrm{C}$ bond formation, as characteristic peaks of benzyl ether $1090 \mathrm{~cm}^{-1}$ were not observed in any case. Polymerization is associated with a high degree of substitution in the benzene ring as proposed by Arana et al. [36] and with formation

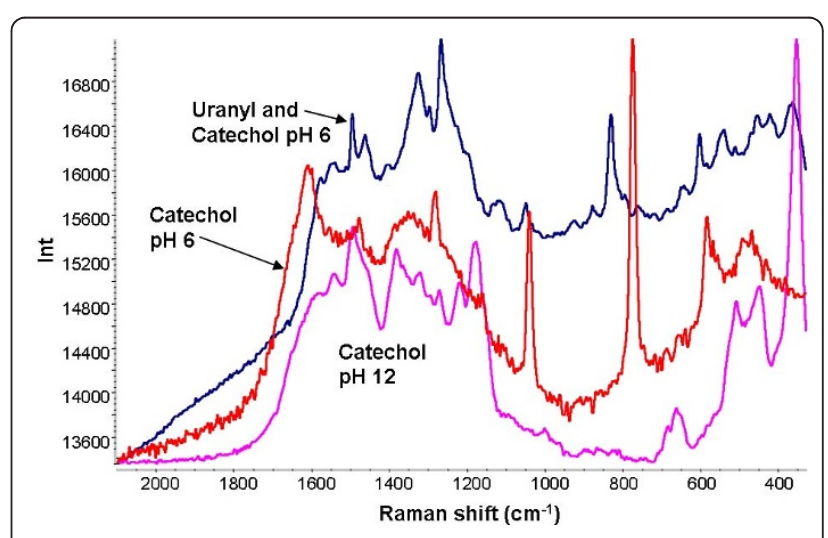

Figure 11 Raman spectra of 1:1 catechol-molybdate at pH6 (a), six month old uranyl-catechol at $\mathrm{pH} 2$ (b) and uranyl-catechol complex at $\mathrm{pH} 6$ (c). 
of quinones [37]. No polymerization was observed under anaerobic conditions, which implies that substitution takes place before polymerization. Formation of quinones and substitution of $\mathrm{H}$ by $\mathrm{OH}$ in the benzene ring may be facilitated by an alkaline environment.

Raman spectra of six month old uranyl/catechol solution were obtained to investigate the effect of time on complexation. All the characteristic peaks of polymerization of catechol were observed even at $\mathrm{pH}$ as low as 2 (Figure 11), whereas a pH of 6 was required for immediate polymerization. Polycatechol formed was found to have precipitated out of solution, likely forming humiclike material. No uranium was found in the precipitate; all the uranyl remained in solution after the polymerization was complete. Hence the uranyl ion in solution acts as a catalyst for formation of polycatechol over time (even under quite acidic conditions) by complex formation with oxygen from hydroxyl and quinone groups.

\section{Conclusions}

In presence of uranyl ions, polymerization was observed even at $\mathrm{pH} 2$ with time. This is likely due to complexation of catechol by uranyl ions with subsequent transfer of electron density from the benzene ring towards uranyl, hence facilitating removal of $\mathrm{H}$ (figure 12). This is consistent with observations by Horsman for catechol polymerization catalyzed by $\mathrm{Fe}(\mathrm{III})$ or by Arana for polymerization catalyzed by $\mathrm{CuO}-\mathrm{TiO}_{2}[38,39]$. After complexation and removal of a second hydrogen from catechol, double bonds between carbon and oxygen atoms are formed with the negative charge on oxygen resulting in quinone and tropone complexed to uranyl ion. This process is associated with depletion of electron density around a neighboring carbon atom in the ring,

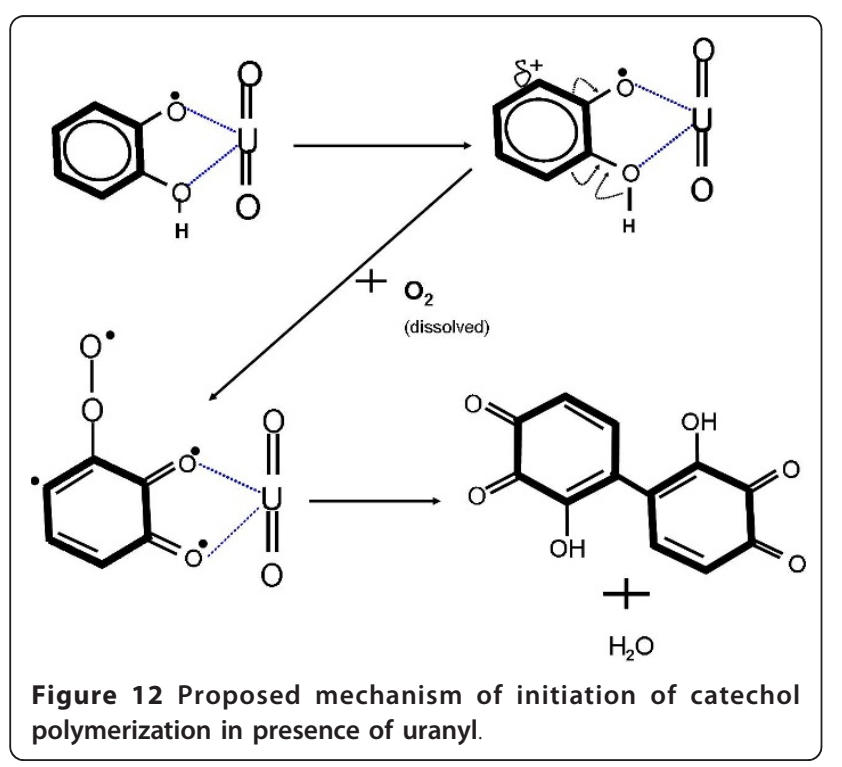

in turn resulting in formation of a single bond with dissolved oxygen. In the next step, an increase in electron density around an adjoining carbon atom leads to formation of a C-C bond between two molecules of catechol. This is the initiation of polymerization - the process continues as uranyl associates with the resulting dimer, in turn leading to $\mathrm{C}-\mathrm{C}$ bonding with additional catechol and so forth. Polymerization of catechol may also be influenced by the formation of a localized zone of high $\mathrm{pH}$ generated by abstracting protons from the solvation[40] shell present around uranyl ions. Recent collaborative work with Kubicki, et al., indicates the inclusion of not only a primary but also a secondary solvation shell of from 20 to 30 water molecules is necessary for accurate quantum mechanical molecular modeling for uranyl-organic ligands, including uranylcatechol [41].

While further study is needed for developing accurate models of the kinetics of long term uranyl association with aromatic molecules with phenolic ligands, this result has a number of significant implications. These include (a) understanding uranium sorption and transportation in surface and some subsurface environments, (b) optimizing the operation of any remediation process which either uses organic ligands or which is used to remove contaminant uranium from groundwater containing natural or pollutant organic material, and (c) for understanding the humification process through oxidative coupling of phenols, as this result shows that uranyl ion can act as a catalyst in the process of polymerization with complexation between catechol ligands and uranyl acting as an intermediate step.

\section{Acknowledgements}

This work has been supported by U.S. Department of Energy Office of Science Environmental Management Science Program (EMSP), contract number DEFG0204ER63729 and the Center for Environmental Molecular Science, (CEMS) funded by the National Science Foundation, contract number CHE0221934.

\section{Authors' contributions}

PKJ designed the experiments acquired and analyzed the data and drafted the manuscript. GPH contributed with conception, revising the manuscript and gave final approval of the version to be published.

\section{Competing interests}

The authors declare that they have no competing interests.

Received: 2 November 2010 Accepted: 11 March 2011

Published: 11 March 2011

\section{References}

1. Stubbs JE, Elbert DC, Veblen DR, Zhu C: Electron microbeam investigation of uranium-contaminated soils from Oak Ridge, TN, USA. Environmental Science \& Technology 2006, 40(7):2108-2113.

2. Abdelouas $A$, Lutze $W$, Nuttall $E$ : Chemical reactions of uranium in ground water at a mill tailings site. Journal of Contaminant Hydrology 1998, 34:343-361.

3. Lottermoser BG, Ashley PM: Tailings dam seepage at the rehabilitated Mary Kathleen uranium mine, Australia. Journal of Geochemical Exploration 2005, 85:119-137. 
4. Brown PL, Guerin M, Hankin SI, Lowson RT: Uranium and other contaminant migration in groundwater at a tropical Australian Uranium Mine. Journal of Contaminant Hydrology 1998, 35:295-303.

5. Winkelmann I, Thomas M, Vogl K: Aerial measurements on uranium ore mining, milling and processing areas in Germany. Journal of Environmental Radioactivity 2001, 53:301-311.

6. Fernandes HM, Franklin MR, Veiga LHS, Freita P, Gomiero LA: Management of uranium mill tailing: geochemical processes and radiological risk assessment. J Environ Radioactivity 1996, 30(I):69-95.

7. Winde F, Jacobus WI: The significance of groundwater-stream interactions and fluctuating stream chemistry on waterborne uranium contamination of streams - A case study from a gold mining site in South Africa. Journal of Hydrology 2004, 287:178-196.

8. Papp Z, Dezso Z, Daroczy S: Significant radioactive contamination of soil around a coal-fired thermal power plant. Journal of Environmental Radioactivity 2002, 59:191-205.

9. Porcelli D, Swarzenski PW: The Behavior of U- and Th- series Nuclides in groundwater. In Uranium-series geochemistry. Volume 52. Edited by: Bourdon, B, Henderson, G.M, Lundstorm, C.C, Turner, S.P. Mineralogical Society of America: Washington, DC; 2003:317-356.

10. Morris DE, Allen PG, Berg JM, Chisholm-Brause CJ, Conradson SD, Donohoe RJ, Hess NJ, Musgrave J, Drew CT: Speciation of uranium in Fernald soils by molecular spectroscopic methods: characterization of untreated soils. Environ Sci Technol 1996, 30:2322-2331.

11. Zhou P, Gu B: Extraction of oxidized and reduced forms of uranium from contaminated soils: Effects of carbonate concentration and $\mathrm{pH}$. Environ Sci Technol 2005, 39:4435-4440.

12. Wood SA: The role of humic substances in the transport and fixation of metals of economic interest (Au, Pt, Pd, U, V). Ore Geology Reviews 1996, 11:1-31.

13. Stevenson FJ: Humus Chemistry: Genesis, composition, reactions. Wiley, New York; 1982

14. Sanchez-Cortes S, Francioso O, Garcia-Ramos JV, Ciavatta C, Gessa C: Catechol polymerization in the presence of silver surface. Colloids and Surfaces A: Physicochemical and Engineering Aspects 2001, 176:177-184.

15. Dec J, Haider K, Bollag J: Release of substituents from phenolic compounds during oxidative coupling reactions. Chemosphere 2003, 52:549-556.

16. Aktas N, Tanyolac A: Reaction conditions for laccase catalyzed polymerization of catechol. Bioresource Technology 2003, 87:209-214.

17. Zeichmann W: Die Darstellung von Huminsauren im heterogenen System mit neutraler Reaktion. Z Pflanzenernaehr Dueng Bodenkd 1959, 84:155-159.

18. Dubey S, Singh D, Misra RA: Enzymatic synthesis and various properties of poly(catechol). Enzyme and Microbial Technology 1998, 23:432-437.

19. Erhan E, Keskinler B, Akay G, Algur OF: Removal of phenol from water by membrane-immobilized enzymes: Part I. Dead-end filtration. Journal of membrane Science 2002, 206:361-373.

20. Colarieti ML, Toscano G, Greco JG: Soil-catalyzed polymerization of phenolics in polluted waters. Water Research 2002, 36:3015-3022.

21. Colarieti ML, Toscano G, Ardi MR, Greco JG: Abiotic oxidation of catechol by soil metal oxides. Journal of Hazardous Materials B 2006, 134:161-168.

22. Zama K, Fukuoka A, Sasaki Y, Inagaki S, Fukushima Y, Ichikawa M: Selective hydroxylation of benzene to phenol by photocatalysis of molybdenum complexes grafted on mesoporous FSM-16. Catalysis Letters 2000, 66(4):251-253.

23. Babcock WC, Friesen DT, Lachapelle ED: Liquid membranes for separating uranium from vanadium and uranium from molybdenum. Journal of Membrane Science 1986, 26:303-312.

24. Buck EC, Wronkiewicz DJ, Finn PA, Bates JK: New uranyl oxide hydrate phase derived from spent fuel alteration. Journal of Nuclear Materials 1997, 249:70-76.

25. Neunhauserer $C$, Berreck $M$, Insam H: Remediation of soils contaminated with molybdenum using soil amendments and phytoremediation. Water, Air, and Soil Pollution 2001, 128:85-96

26. Gorman-Lewis D, Fein JB, Burns PC, Szymanowski JES, Converse J: Solubility measurements of the uranyl oxide hydrate phases metaschoepite, compreignacite, Na-compreignacite, becquerelite, and clarkeite. Journal of Chemical Thermodynamics 2008, 40:980-990.
27. Fujii T, Fujiwara K, Yamana H, Moriyama H: Raman spectroscopic determination of formation constant of uranyl hydrolysis species $\left(\mathrm{UO}_{2}\right)_{2}$ $(\mathrm{OH})_{2}{ }^{2+}$. Journal of alloys and compounds 2001, 323-324:859-863.

28. Maximovitch S, Barral G, Le Cras F, Claudet F: Electrochemical incorporation of molybdenum in the passive layer of a $17 \% \mathrm{Cr}$ ferritic stainless steel. Its influence on film stability in sulphuric acid and on pitting corrosion in chloride media. Corrosion Science 1995, 37(2):271-291.

29. Duarte RMBO, Santos EBH, Duarte, Armando C: Spectroscopic characteristics of ultrafiltration fractions of fulvic and humic acids isolated from an eucalyptus bleached Kraft pulp mill effluent. Water Research 2003, 37:4073-4080.

30. Miyasaka M, Yamazaki T, Tsuchida E, Nishide H: Regioregular polythiophene with pendant phenoxyl radicals: a new high-spin organic polymer. Macromolecules 2000, 33:8211-8217.

31. Shin YT, Shin SW, Shin J, Lee K, Cha M: Pulsed laser deposition of a thin conjugated-polymer film. Thin Solid Films 2000, 360:13-16.

32. Bruno FF, Nagarajan R, Stenhouse P, Yang K, Kumar J, Tripathy SK, Samuelson LA: Polymerization of water-soluble conductive polyphenol using horseradish peroxidase. J Macromol Sci- Pure Appl Chem 2001, A38(12):1417-1426.

33. Zille A, Gornacka B, Rehorek A, Cavaco-Paulo A: Degradation of azo dyes by Trametes villosa laccase over long periods of oxidative conditions. Applied and environmental microbiology 2005, 71(11):6711-6718.

34. Gulley-Stahl H, Hoganii PA, Schmidt WL, Wall SJ, Buhrlage A, Bullen HA: Surface Complexation of Catechol to Metal Oxides: An ATR-FTIR, Adsorption, and Dissolution Study. Environ Sci Technol 2010, 44:4116-4121.

35. Mazoyer P, Geantet C, Diehl F, Loridant S, Lacroix M: Role of chelating agent on the oxidic state of hydrotreating catalysts. Catalysis Today 2008, 130:75-79.

36. Arana J, Rendon ET, Rodriguez JMD, Melian JAH, Gonzalez O, Pena JP. Highly concentrated phenolic wastewater treatment by the PhotoFenton reaction, mechanism study by FTIR-ATR. Chemosphere 2001, 44:1017-1023.

37. Borraccino R, Kharoune M, Giot R, Agathos SN, Nyns EJ, Naveay HP, Pauss A: Abiotic transformation of catechol and 1-naphthol in aqueous solutionInfluence of environmental factors. Water Research 2001, 35(15):3729-2737.

38. Horsman GP, Jirasek A, Vaillancourt FH, Barbosa CJ, Jarzecki AA, Xu C, Mekmouche Y, Spiro TG, Lipscomb JD, Blades MW, Turner RFB, Eltis LD: Spectroscopic studies of the anaerobic enzyme-substrate complex of catechol 1,2-dioxygenase. Journal of American Chemical Society 2005, 127:16882-16891.

39. Arana J, Fernandez RC, Gonzalez DO, Herrera MJA, Perez PJ: Role of Cu in the $\mathrm{Cu}-\mathrm{TiO}_{2}$ photocatalytic degradation of dihydroxybenzenes. Catalysis Today 2005, 101:261-266

40. Sever MJ, Wilker JJ: Visible absorption spectra of metal-catecholate and metal-tironate complexes. Dalton Trans 2004, 1061-1072.

41. Kubicki J, Halada G, Jha P, Phillips B: Quantum Mechanical Calculation of Aqueous Uranium Complexes: Carbonate, Phosphate, Organic and Biomolecular Species. Chem Cent J 2009, 3:10.

doi:10.1186/1752-153X-5-12

Cite this article as: Jha and Halada: The catalytic role of uranyl in

formation of polycatechol complexes. Chemistry Central Journal 2011 5:12.

\section{Publish with ChemistryCentral and every scientist can read your work free of charge \\ "Open access provides opportunities to our colleagues in other parts of the globe, by allowing anyone to view the content free of charge." W. Jeffery Hurst, The Hershey Company. \\ - available free of charge to the entire scientific community \\ - peer reviewed and published immediately upon acceptance \\ - cited in PubMed and archived on PubMed Central \\ - yours - you keep the copyright \\ Submit your manuscript here: \\ http://www.chemistrycentral.com/manuscript/ \\ ChemistryCentra}

